\title{
Evaluation of the advantages of usage of containers in Housing production in terms of sustainability
}

\author{
Ecem Akar \\ İTÜ Istanbul Technical University, Interior Architecture Department, IMIAD, Turkey, \\ Dr. Müge Belek Fialho Teixeira \\ [f]FLAT Architectures, 33A Ganges Street, West End, QLD 4101, Brisbane, Australia \\ Assoc. Prof. Dr. Deniz Ayşe Yazıcıoğlu \\ Istanbul Technical University, Interior Architecture Department, Taşkışla, 34437 Taksim \\ Istanbul/Turkey
}

\begin{abstract}
Sustainable building construction aims to create a system that provides people with humanely and equitable economic opportunities through the harmony of the built environment with the natural environment. To this end, different approaches are utilized such as re-functioning, use of environmentally friendly methods in production, employment of building items suitable for climate and topography, consideration of energy efficiency in the building life cycle, utilization of renewable energy sources, use of local or traditional materials and minimization of waste generation during construction and destruction process of buildings. One of the most popular approaches among these is the "utilization of containers in the production of sustainable buildings", which is a sub-field of the re-functioning approach. In this context, the objective of this study is to evaluate the advantages of utilization of containers in the production of sustainable buildings through a systematic approach. However, the realization of this assessment within a single study for all building types is quite difficult to achieve as a scientifically significant result. As such, as a methodology, the first stage of the study will determine which structure type should be considered. Subsequently, the criteria to be based on, in the evaluation of the advantages of producing this structure type (containers) in terms of sustainability will be described. At the last stage, certain criterias that the containers should meet in line with the data obtained from the literature will be determined.
\end{abstract}

Keywords: Design of sustainable housing, re-functioning in the construction industry, utilization of containers in housing production

\section{INTRODUCTION}

The term "Ecology" has been used in the "General Morphology" work of Ernst Haeckel, to identify all kinds of information about the economy of nature and determine the organic and inorganic environmental relations of animals. Haeckel has been inspired by the idea of the economy of nature, mentioned by Charles Darwin in his book titled "Origin of Species" published in 1859, while preparing this work and developed this idea under the ecology term of Thoreau [1]. Much as ecology was accepted as a science only in the 19th century, humanity has been intertwined with ecology since the creation of mankind [2]. In this context, human being had no purpose to be superior to the natural surroundings according to the mechanistic view [3]. However, human beings have began to think that they can change nature as they wish with developments in industrialization, urbanization and technology. Humans have tried to make the nature adapt to themselves instead of living in harmony with nature within the 
whole ecosystem. This understanding has led to the natural resources to be consumed unconsciously or made them unusable, and in this way numerous global problems have arisen. Construction industry has been considered as one of the most important stakeholders of this destruction, hence global warming. According to an article published by the American Institute of Architecture (AIA), the construction sector is at the top of the list, according to data showing distribution of emissions by sectors [4].

Destruction of ecology over time has required the emergence of new understandings and trends. Modern analysis techniques and technology have come together to take the first steps of today's environmentalist movement in the 1950s and 1960s. The idea of not living "against nature" but living "with nature", which has emerged in this period, has revealed how the way followed in the world's most advanced industries and countries is wrong [5]. In this way, the term "sustainability", which is one of most commonly concepts of today, has begun to be addressed for the first time in 1970s [6].

Sustainability is the continuous processing capability of a society, ecosystem or other similar interactive systems without consuming the basic resources thereof and without adversely affecting the environment [7]. Sustainable design comprises strategic use of design to meet the current and future humanitarian needs without harming the environment [8]. Sustainable design determines the relation of products and periods with the environmental, economic and social systems that surround them and develops approaches to prevent non-sustainable effects in these systems. [9]. Sustainable design in the construction industry has begun to show a significant movement since 2000s. Sustainable building production aims to create a system that provides people with humanely and equitable economic opportunities with the harmony of natural environment and the structures built in this environment [10]. To this end, different approaches are utilized such as re-functioning, use of environmentally friendly methods in production, employment of building items suitable for climate and topography, consideration of energy efficiency in the building life cycle, utilization of renewable energy sources, use of local or traditional materials and minimization of waste generation during construction formation and destruction process of buildings. One of the most popular approaches among these is the "utilization of containers in production of sustainable buildings", which is a subfield of the re-functioning approach. The most important reason for this is that the containers are being manufactured at very high rates and they are being replaced after an average of 7 years by most of the transport companies and in this case hundreds of containers that have not yet reached their lifespan are turned into high quality waste [11]. According to data obtained in 2008, approximately $80 \%$ of the world transportation is carried out by containers [12]. According to the World Bank, in 2010, a total of 542.2 million TEU (Twenty-foot Equivalent Unit) containers were carried around the world. In 2014, this figure has increased to 679.2 million TEU [13].

This apparent increase in container traffic has also accelerated container production. There are 20.28 million TEU containers actively used for transportation in the world currently according to most recent statistics [14]. When the container manufacturers with the largest share in the container production market in the world are examined, the current orders received by the leading companies reveal that there will be further increases in the cited numbers in the coming periods. For example; APM-Maersk, indicated as the largest container producer in the world and which has 3,25 million TEU containers, has 367.130 units of pending container orders for 2017. The expected increase in container production between 2014 and 2017 is 
$5.3 \%$ [15]. Containers that are produced at high rates, will be turned into high quality waste in a very short time.

The scope of the work, in line with all these data obtained from the literature is to assess the advantages of the use of containers, with "re-functioning approach" in building production in terms of sustainability with a systematic approach.

\section{PURPOSE AND METHODOLOGY}

The objective of the study is to assess the advantages of the use of containers in building production in terms of sustainability with a systematic approach. However, the realization of this assessment within a single study for all building types is quite difficult to achieve as a scientifically significant result. As such, as a methodology, the first stage of the study will determine which structure type should be considered. Subsequently, the criteria to be based on, in the evaluation of the advantages of producing this structure type (containers) in terms of sustainability will be described. At the last stage, whether the usage of the containers in the housing production is appropriate enough in terms of sustainability and certain criterias the containers should meet in line with the data obtained from the literature will be determined.

\section{Determination of the building type to be considered in the scope of the study}

The types of buildings are divided into different categories within the classification systematic systems defined in line with the aimed usage in the construction sector having a big share in ecological damage and annual energy consumption. These categories show great similarities as much as they are defined separately for each and every country. The buildings are divided into five categories in the classification system of Turkey, and their features are described within the purview of the communiqué on "Approximate Unit Costs to be Used in the Account of Architectural and Engineering Service Charges" promulgated through the Ministry of Environment and Urbanization every year in the Official Gazette [16]. Many institutions such as the Chamber of Architects of Turkey, the Chamber of Mechanical Engineers of Turkey and the Chamber of Interior Architects of Turkey accept the types of buildings specified in this communiqué.

When the structural building types defined in the classification system in Turkey are evaluated in terms of their production rates, it is observed that the production rate of the "residential" building type is much higher than the other building types. One of the most significant statistical data revealing this situation with full clarity is the counting results of the amount of buildings as of 2010 by the Turkish Statistical Institute (TÜIK) specified in the Current Situation Assessment Report of Turkey's Climate Change National Action Plan Development Project. The percentage of building types in the building stock according to the purpose of use is $75 \%$ according to these results, [17]. Furthermore, again according to the counting results of the amount of buildings as of 2010 by the Turkish Statistical Institute (TÜIK) , the number of buildings was 4.3 million in 1984 and increased by $78 \%$ in 2000 to 7.8 million while the number of houses reached 16.2 million with a $129 \%$ increase in the same year [18]. When these rates are taken into account, it is observed that the ratio of houses in the number of existing building stock and the types of buildings produced is much higher.

Furthermore, as a result of the literature studies, it has been observed that the energy consumption of houses is very high compared to the total energy consumption. It is observed when the distribution of TÜİK (Turkish Statistical Institute) Net Electricity Consumption by Sectors is examined that $25 \%$ of electric energy consumption which was $156,894 \mathrm{GWh}$ in total in 2009 was made by residences [19]. 20\%,31\%, 20\%, 14\% and $11 \%$ of the total energy 
consumption in houses in Turkey is met by coal with low thermal value and high humidity and sulfur content; wood obtained from forests which are very important to keep the atmosphere combination in balance and which increase emission of CO2; petrol; animal and plant residues; natural gas which is the reason of 3\% of the CO 2 emissions; and electricity respectively. [20] When the data of TÜIIK (Turkish Statistical Institute) dated 1998 as to Fuel Consumption for House Lighting and Heating table is examined, it is observed that 1,043,398 tons of fuel oil with high sulfur content has been employed for heating the houses in one year [21].

In this context, it has been decided that the building type within the scope of the study will be "residential", as it is the most produced building type in Turkey, as well as it has having a significant share in energy consumption of Turkey.

\section{Determination of the criteria to be based on the evaluation of the advantages of container utilization in housing production in terms of sustainability}

A literature research has been carried with intend to determine the criteria to be taken into consideration in evaluating the advantages of container employment in terms of sustainability in housing production $[22 ; 23 ; 24 ; 25 ; 26 ; 27 ; 28 ; 29 ; 30 ; 31 ; 32 ; 33 ; 34 ; 35 ; 36 ; 37 ; 38 ; 39 ; 40$; $41 ; 42 ; 43 ; 44 ; 45 ; 46 ; 47 ; 48 ; 49 ; 50 ; 51 ; 52 ; 53 ; 54 ; 55]$. As a result of these researches, it has been decided to base the study on the following evaluation criterias in line with the data obtained:

1. Easy access to materials,

2. Effective use of energy during production process,

3. Less waste generation during production process,

4. Lower production costs,

5. Lower transportation costs,

6. Efficient use of energy during life cycle,

7. Recyclability,

8. Reusability,

9. Conformance with building biology

A literature research has been carried out to evaluate the advantages of container employment in terms of sustainability in housing production according to the criteria listed hereinabove $[11 ; 56 ; 57 ; 58 ; 59 ; 60 ; 61 ; 62 ; 63 ; 64 ; 65 ; 66 ; 67 ; 68 ; 69 ; 70 ; 71 ; 72]$, and the data obtained are the same as the ones provided in Table 1 . 
Tablo 1. Evaluation of benefits of container usage in housing production in terms of sustainability

\begin{tabular}{|c|c|c|c|c|c|c|c|c|c|c|c|c|c|c|c|c|c|c|}
\hline \multirow[b]{2}{*}{ Evaluation criteria } & \multicolumn{18}{|c|}{ Literature } \\
\hline & $\Xi$ & 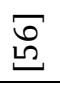 & 든 & 㐫 & a & 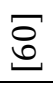 & $\overline{\vec{b}}$ & $\widetilde{\widetilde{U}}$ & లై & $\underset{F}{F}$ & 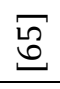 & $\underset{\varnothing}{\varnothing}$ & $\widehat{\widehat{\sigma}}$ & $\underset{\infty}{\infty}$ & જ઼ & $\stackrel{\circ}{尺}$ & $\Xi$ & $\stackrel{\Sigma}{N}$ \\
\hline Easy access to materials & $\mathrm{X}$ & & & $\mathrm{X}$ & & & & $\mathrm{X}$ & $\mathrm{X}$ & $\mathrm{X}$ & & & $\mathrm{X}$ & & $\mathrm{X}$ & $\mathrm{X}$ & $\mathrm{X}$ & $\mathrm{X}$ \\
\hline $\begin{array}{l}\text { Effective use of energy during } \\
\text { production process }\end{array}$ & & $X$ & $\mathrm{X}$ & $\mathrm{X}$ & $\mathrm{X}$ & $X$ & & $\mathrm{X}$ & $X$ & & & $\mathrm{X}$ & & $\mathrm{X}$ & $\mathrm{X}$ & $\mathrm{X}$ & & \\
\hline $\begin{array}{l}\text { Less waste generation during } \\
\text { production process }\end{array}$ & & & $\mathrm{X}$ & & & & & & $X$ & & & $\mathrm{X}$ & & & $\mathrm{X}$ & $\mathrm{X}$ & & $\mathrm{X}$ \\
\hline Lower production costs & & $\mathrm{x}$ & $\mathrm{x}$ & $\mathrm{x}$ & $\mathrm{x}$ & $\mathrm{X}$ & $\mathrm{X}$ & $\mathrm{X}$ & $\mathrm{X}$ & $\mathrm{X}$ & $\mathrm{X}$ & $\mathrm{X}$ & $\mathrm{X}$ & $\mathrm{X}$ & $\mathrm{x}$ & $\mathrm{X}$ & $\mathrm{x}$ & $\mathrm{X}$ \\
\hline Lower transportation costs & & & $\mathrm{X}$ & $\mathrm{X}$ & & $\mathrm{X}$ & $\mathrm{X}$ & & $\mathrm{X}$ & & & & & & $\mathrm{X}$ & & $\mathrm{X}$ & \\
\hline $\begin{array}{l}\text { Efficient use of energy during life } \\
\text { cycle }\end{array}$ & $\mathrm{X}$ & & $\mathrm{X}$ & & & $\mathrm{X}$ & & & $X$ & $\mathrm{X}$ & & $\mathrm{X}$ & & & & $\mathrm{X}$ & & \\
\hline Recyclability & $\mathrm{X}$ & & & $\Lambda$ & $\mathrm{X}$ & & & & & & & & & & & & & \\
\hline Reusability & $\mathrm{X}$ & & & $\mathrm{X}$ & $\mathrm{X}$ & $\mathrm{X}$ & & $\mathrm{X}$ & $\mathrm{X}$ & $\mathrm{X}$ & & $\mathrm{X}$ & $\mathrm{X}$ & & $\mathrm{X}$ & $\mathrm{X}$ & $\mathrm{X}$ & $\mathrm{X}$ \\
\hline $\begin{array}{l}\text { Conformance with building } \\
\text { biology }\end{array}$ & $X$ & X & $\mathrm{X}$ & $\mathrm{X}$ & X & $X$ & $X$ & $X$ & $X$ & $X$ & $\mathrm{X}$ & $X$ & $\mathrm{X}$ & $\mathrm{X}$ & & & & \\
\hline
\end{tabular}

It was seen that the containers met all of the evaluation criteria determined based on 34 different sources when the data in Table 1 were evaluated. Containers' allowing housing production at very low cost is the most emphasized feature in terms of sustainability. This feature has a special significance for the construction sector in which production costs are very high. Furthermore, it was concluded as a result of the literature research done that the containers have substantial additional features in terms of sustainability in addition to the evaluation criteria described in Table 1 inasmuch as they are resistant to difficult climate conditions, have longevity, are not easily damaged while being transported from one place to another, are prefabricated and modular and their construction process takes short time and is easy. It has been observed that the utilization of containers in the production of housing in line with all these obtained data will furnish significant advantages in terms of sustainability.

\section{RESULTS}

Increase of container usage in housing production will allow the re-functioning of this material providing liveable spaces which has superior qualities of sustainability in terms of availability, workforce, waste generation and cost reductions and efficient energy use. This application will reduce material consumption in the construction sector and provide substantial contributions to the efficient use and protection of natural resources.

\section{References}

Beyaztaş, H. S. (2012). Mimari Tasarımda Ekolojik Bağlamda Biçim ve Doğa İlişkisi Yüksek Lisans Tezi, İtü Mimarlık Fakültesi Kütüphanesi, pp. 21.

Sözen, N. (1992). İnsan Çevre Toplum: Yeşil Saygısının Evrensel Kuralları, İmge Kitabevi Yayıncılık, Ankara.

Bilgen,S. (2011). Ekolojik Mimarlık: Anti-Ekolojik Bir Eylem ile “Ekoloji” Söyleminin Bir Araya Gelme Biçimleri Yüksek Lisans Tezi, İtü Mimarlık Fakültesi Kütüphanesi, pp. 6.

AIA. (2016). Architects and Climate Change Fact Sheet.

Mirvis, P. H. (1994). Environmentalism in Progressive Businesses, Journal of Organizational Change Management. 7/4, 82-100. 
Kamara, M., Coff, C.and Wynne, B. (2006). GMO's and Sustainability, Accessed 25 October 2016, <http://itsma.blogs.com/verge/corporate responsibility/index.html>

Peterson, K. L., Dorsey, J. A. (2000). Roadmap for Integrating Sustainable Design into Site-Level Operations, Prepared for the U.S. Department of Energy, Pacific Northwest National Laboratory, Richland, Washington 99352,The Brendle Group, Inc., Ft. Collins, Colorado.

British Design Council. (2007). Sustainable Design, Climate Change and Built Environment Guide.

Glavanich, T. E. (2008). Contractor's guide to green building construction, - management, project delivery, documentation, and risk reduction, John Wiley and Sons, Inc.,Hoboken, New Jersey.

Yorgancıoğlu, P. (2004). Sürdürülebilir Yapım Kavramının Uygulamaya Aktarılmasındaki Araç, Yöntem ve Yaklașımlara İlișkin Bir Değerlendirme Yüksek Lisans Tezi, İtü Mimarlık Fakültesi Kütüphanesi, pp. 29.

ISBU. (2010). Container Technology A-Z. Green Cube Publishing, USA.

Ebeling, C. E. (2009). "Evolution of a Box". Invention and Technology.

World Bank. (2014). Container Port Traffic, Accessed 10 December

2016,<http://data.worldbank.org/indicator/IS.SHP.GOOD.TU>

The Statistics Portal. (2016). Projected global container market demand growth between 2003 and 2018, Accessed 27 November 2016, <https://www.statista.com/statistics/253931/global-container-market-demand-growth/ >

Resmi Gazete. (2016). Mimarlık ve Mühendislik Hizmet Bedellerinin Hesabında Kullanılacak 2016 Yılı Yapı Yaklaşık Birim Maliyetleri Hakkında Tebliğ, Number: 29679.

TÜíK. (2010). 2010 Bina Sayımı.

Keskin, T. (2010). Türkiye'nin İklim Değişikliği Ulusal Eylem Planı'nın Geliştirilmesi Projesi Mevcut Durum Değerlendirilmesi Raporu, pp.8.

TÜIK. (2014). Net Elektrik Enerjisi Tüketiminin Sektörlere Göre Dağılımı.

Dilmaç, Ş and Tırıs, M. (2013). Türkiye’de Konut Sektöründe Enerji Tasarrufu.

TÜiK. (1998). Konutların Aydınlatma ve Isıtma Amaçlı Yakıt Tüketimi.

Çağnan, C.. and Özer, H. (2014). Yapı Üretiminde Sistem Yaklașımı ile Yapı Ürünü Performanslarının Çevre-Ekoloji ve Yasal Zorunluklar Bağlamında Test Edilmesine Yönelik Bir Model Önerisi, Megaron, 9(4), pp.255-270.

Erdede, S.B, Erdede, B and Bektas, S. (2014). Sürdürülebilir Yeșil Binalar ve Sertifika Sistemlerinin Değerlendirilmesi, Uzaktan Algılama-Cbs Sempozyumu (UZAL-CBS 2014), 14-17 October 2014, İstanbul.

Erdede S.B. and Bektaş S. (2014). Ekolojik Açııan Sürdürülebilir Taşınmaz Geliştirme ve Yeşil Bina Sertifika Sistemleri, Harita Teknolojileri Elektronik Dergisi, 6(1), pp. 1-12

Bilgin, E. ve Utkutuğ, G.S. (1999). Tasarım ve Üretim Sürecinde Mimar-Mühendis İş Birliğini Yansıtan Üç Örnek Bina, IV.Ulusal Tesisat Mühendisliği Kongresi ve Sergisi Bildiriler Kitabı, TMMOB Makina Mühendisleri Odası, İzmir.

Yaka, İ.F., Önal, S., Koçer, A. and Güngör A. (2016). Comparison of Building Energy Performance of Different Provinces, The Journal of Global Engineering Studies, Volume: 3 Issue:2, pp.127-135.

Demirarslan, S. and Demirarslan, O. (2015). Sürdürülebilir Çevre Uygulamalarında Mimarın Rol ve Sorumluluğu, Anadolu Doğa Bilimleri Dergisi 6 (Özel Sayı 2), pp. 220-230.

Yılmaz, B., Arditi, D. and Korkmaz, S. (2010). Yüksek Performanslı (Yeşil) Binalarda Bütünleşik Tasarım Sistemi, 1. Proje ve Yapım Yönetimi Kongresi, 29 September-1 October 2010, ODTÜ Kültür ve Kongre Merkezi, Ankara

Polat, T. (2016). Sürdürülebilir Kentleşme Politikaları ve Türkiye, International Periodical for the Languages, Literature and History of Turkish or Turkic, Volume 11/2 Winter, pp. 1267-1300.

Özsoy, E.A. and Erden Özsoy, C. (2015). Yeşil Ekonominin Bir Gereği Olarak Yeşil Binalar ve Türkiye'de Mesleki Eğitim İçin Yeni Açlımlar, EJOİR ARALIK 2015 IWCEA, Özel Sayısı, Cilt 1.

Şenöz, E., Çabuk, S.N. and Çabuk, A. (2014). Geotasarım Kuramının Alpagut Beldesi'nde Deneyimlenmesi, Teknolojik Araştırmalar: HTED (2), pp.12-26. 
Değerliyurt, M. and Çabuk, S.N.(2015). The Theory of Mcharg: Design With Nature and Geodesign, International Journal of Social Science, Number: 39, pp. 293-306.

Çabuk, S.N. (2014). Designing with Geographical Information Systems: Geodesign Concept, Electronic Journal of Map Technologies, Vol: 6, No: 1, pp.37-54.

Dalonzo, M.M. and Ciravoğlu, A.(2015). Ülkemizde Mimarların Yapı Ürünü Seçimlerinin Çevresel, Toplumsal ve Ekonomik Açıdan Değerlendirilmesi, Megaron, Vol.10/2, pp.1-10.

Okay, S.Ö. and Özyılmaz Küçükyağcı, P. (2015). Üniversite Kampüslerinde Sürdürülebilir Tasarım Sürecinin İrdelenmesi, II.Uluslararası Sürdürülebilir Yapılar Sempozyumu, 28-30 Mayıs 2015, Türkiye.

Ünal, A.G. (2014). Ankara Sinpaş Altınoran Konut Projesi ve Ekolojik Tasarım, Planlama, Vol.24/2., pp.95-106.

Uslusoy Şenyurt, S. and Altın, M. (2014). Enerji Etkin Tasarımın Çatı ve Cephelere Yansıması, 7. Ulusal Çatı \& Cephe Sempozyumu 3 - 4 April 2014, Yıldız Teknik Üniversitesi, İstanbul.

Aydın, Ö. and Lakot Alemdağ, E.(2014). Sustainable Materials in Black Sea Vernacular Architecture; Wood and Stone, The Journal of International Social Research, Vol.7, Issue.35, pp.394-405.

Erol, Ö. (2013). Yüksek Performanslı Binaların Tasarımında Bina Benzetim Yazılımlarının Yeri, 11. Ulusal Tesisat Mühendisliği Kongresi ve Sergisi Bildiriler Kitabı, TMMOB Makina Mühendisleri Odası, İzmir, pp.1703-1716.

Özorhon, G. (2013). Sürdürülebilir Mimarlık, Yarının Binaları ve Bir Örnek, 11. Ulusal Tesisat Mühendisliği Kongresi ve Sergisi Bildiriler Kitabı, TMMOB Makina Mühendisleri Odası, İzmir, pp.1473-1478.

Bostancıŏ̆lu, E. (2010). Konutlarda Duvar ve Çatı Yalıtımlarının Bina Kabuğu, Isıtma Enerjisi ve Yașam Dönemi Maliyetleri Üzerindeki Etkisi, Uludağ Üniversitesi Mühendislik-Mimarlık Fakültesi Dergisi, Cilt 15, No.1, pp.135147.

Arslan Selçuk, S. and Gönenç Sorguç, A.(2007). Impact of Biomimesis in Architectural Design Paradigm, J. Fac. Eng. Arch. Gazi Univ., Vol 22, No 8, pp.451-459.

Erten, D. and Yılmaz, A.Z. (2011). LEED ve BREEAM Sertifikalarında Enerji Performans Değerlendirilmesinin Karşılaştırılması, 10. Ulusal Tesisat Mühendisliği Kongresi ve Sergisi Bildiriler Kitabı, TMMOB Makina Mühendisleri Odası, İzmir, pp.1541-1552.

Kabuloğlu Karaosman, S. (2011). Mimarlık Eğitiminde Seçenekten Zorunluluğa; Ekolojik Tasarım, Güney Mimarlık, No.6, pp.63-67.

Türkmenoğlu Bayraktar, N. (2011). Sürdürülebilir Mimarlık Bağlamında Geleneksel Mimaride Ekolojik Yaklaşımlar, Güney Mimarlık, Sayı.6, pp.19-22.

Uzun, T. (2011). Yeşil Bina Değerlendirme Sistemleri ve Türkiye İçin Yol Haritası, Güney Mimarlık, No.6, pp.36-42.

Oktay, D. (2011). Mimarlık ve Sürdürülebilirlik: Güncel Bir Değerlendirme ve Öneriler, Güney Mimarlık, No.6, pp.14-16.

Tekin, Ç. and Kurugöl, S.(2011). Environment- Friendly Three Buildings Based on Three Living Creatures, eJournal of New World Sciences Academy, Vol. 6, No. 4, pp. 943-952.

Esin, T. and Yüksek, İ.(2009). Çevre Dostu Ekolojik Yapılar, 5. Uluslararası İleri Teknolojiler Sempozyumu (IATS'09), 13-15 May 2009, Karabük, Türkiye

Anbarcl, M., Giran, Ö. and Demir, H. (2012). International Green Building Certification Systems and Building Energy Efficiency Implementation In Turkiye, e-Journal of New World Sciences Academy, Vol. 7, No. 1, pp. 368383.

TMMOB Mimarlar Odası. (2007). Sürdürülebilirlik: Kent ve Mimarlık, TMMOB Mimarlar Odası-Ankara Şubesi.

Erkınay, P.U. and Erten E. (2010). Binalarda Yenilenebilir Teknolojilerin Kullanımındaki Gelişim ve Bu Gelişimin Türkiye'ye Yansıması, 1. Uluslararası Lisansüstü Araştırmaları Sempozyumu; Yapılı Çevre, ODTÜ, Ankara, Turkiye, 15-16 October 2010.

Öcal, C. and İnce, H.H.(2012). Sürdürülebilir Yapı Tasarımı ile Değişen İhtiyaçlar, International Construction Congress 2012, ICONC2012-SDÜ.

Cakmanuz, İ, Kaş, I, Künar, A and Gülbeden, A.(2010). Yüksek Performanslı Sürdürülebilir Binalara İlişkin Bir Değerlendirme, Yeşil Bina Dergisi, Vol.3(4), pp. 461-462. 
Dikmen, Ç.B. (2011). Enerji Etkin Yapı Tasarım Ölçütlerinin Örneklenmesi, Politeknik Dergisi, Vol.14 No.2, pp. 121-134.

Altun, D.A. (2009). Sürdürülebilir, Enerji Korunumlu Bir Mimarlıkta 'TASARIM', Ege Mimarlık, No.January, pp.2833.

Belhaouari, H. and Peschanski, F. (2008). A Lightweight Container Architecture for Runtime Verification. Springer - Verlag, Berlin.

CIMC Building Systems. (2016). What is Modular Construction?, Accessed 27 December 2016, <http://www.cimcmbs.com/wm/index_115.aspx>.

Eko Yapı Dergisi. (2014). Kutu Kutu Yaşam Konteyner Mimarisi, Accessed 27 December 2016, <http://www.ekoyapidergisi.org/807-kutu-kutu-yasam-konteyner-mimarisi.html>.

Forrest, A. (2015). Living in a Steel Box: Are Shipping Containers Really the Future of Housing?, The Guardian.

Garcia, M. (2014). Alternative Housing: The Shipping Container Home, National Association of Realtors.

Garrido, L. (2015). Green Container Architecture 3. Monsa Publishers, Spain.

Kalkin, A. (2004). Quik House. Kalkin\&Co., USA.

Olivares, A. A. P. (2010). Sustainability in Prefabricated Architecture, A comparative Life Cycle analysis of Container Architecture for Residential Structures. Victoria University of Wellington, Thesis.

Radwan, A. H. (2015). Reusing Shipping Containers in Creating Various Architectural Spaces. Helwan University Architecture Department, College of Fine Arts.

Reynolds, E. and Sural, E. (n.d.). Container City Answers to Frequently Asked Questions.Urban Space, UK.

Robinson, A. and Swindells, T. (2012). Customized Container Architecture. ACSA Fall Conference.

Socrates, N. (2012). Container Homes.

Taşçı, M. (2016). Konteyner Mimarisi, Projem, Accessed 27 December 2016,

<http://www.projem.com.tr/haber/71/konteyner-mimarisi> .

Santa Cruz Architect.(2016). Shipping Container Architecture: Advantages and Challenges, Accessed 30 December 2016, <https://santacruzarchitect.wordpress.com/2014/05/20/shipping-container-architecture-advantagesand-challenges/>

Marine in Sight. (2016). 7 Benefits of Shipping Container Home Design, Accessed 30 December 2016, <http://www.marineinsight.com/recreation/7-benefits-of-shipping-container-home-design/>

Investopedia. (2016). Shipping Container Homes: The Costs and Benefits, Accessed 30 December 2016, <http:/www.investopedia.com/articles/personal-finance/073016/shipping-container-homes-costs-and-benefits.asp>

Icontainers. (2016). Shipping container homes, Accessed 30 December 2016, <http://www.icontainers.com/us/2016/12/15/shipping-container-homes/>. 